International Journal of Agriculture, Environment and Bioresearch

Vol. 4, No. 06; 2019

ISSN: $2456-8643$

\title{
PRODUCTIVITY VARIATION OF ANGORA RABBITS UNDER EXOGENOUS PMSG AND HCG HORMONES
}

\author{
Fadli M.Z ${ }^{1}$, Mudawamah Mudawamah ${ }^{2}$ and Oktavia R.P. ${ }^{2}$ \\ ${ }^{1}$ Depart. of Medical, University of Islam Malang \\ ${ }^{2}$ Depart. of Animal Husbandry, University of Islam Malang \\ Correspondence author: mudawamah@unisma.ac.id
}

http://doi.org/10.35410/IJAEB.2019.4485

\begin{abstract}
The study aimed to observe the response of Angora doe rabbits treated with gonadotrophin, intramuscular based on litter size and birth weight of kits. The samples used ten does that had given birth once and three bucks, which had been sexually mature and were able to perform their reproductive functions. This study used an experimental method by administering gonadotrophin hormones in the form of PMSG and HCG. Data analyzed by unpaired t-test with Excel. The observed variables were litter size and birth weight, with five replications. The observations showed that the administration of PMSG and HCG had a very significant effect $(\mathrm{P}<0.01)$ on litter size and birth weight. The average litter size of rabbits treated with PMSG and HCG hormones was $61.53 \%$ higher than the litter size of controls followed by low variation in treatment than controls (1.30 vs. 1.80). Exogenous PMSG and HCG hormones decreased birth weight by $14.48 \%$ compared to controls with more diverse variance compared to controls (19.27 vs. 3.06). The conclusion of this study was the administration of PMSG and HCG hormones to rabbits reduce variation (increase uniformity) followed by an increase in the average productivity of livestock in the litter size at birth, followed by birth weight of kits who fulfill minimum standards.
\end{abstract}

Keywords: Superovulation, litter size, birth weight, rabbit.

\section{INTRODUCTION}

The initial target of raising rabbits in Indonesia was an alternative to meet the needs of animal protein that was increasing from year to year in Indonesia, especially in malnutrition in rural areas. Now, rabbits have developed into livestock businesses that can increase family income as a very profitable side business. Rabbit demand is rising along with the development of culinary (rabbit satay) in restaurants, especially in the province of East Java. Besides, the Rabbit population is widely spread in the tourist area and become one of the attractions of tourists to come and buy rabbits as pets.

One of the indicators of profitable rabbit livestock business was having does with large litter size and followed by good growth to obtain optimal adult weight. On the other hand, the 
problem of raising rabbits, including Angora was a much variation of litter size, supported by the opinion Kumar et al., (2005) ${ }^{1}$ that the variance value of German Angora rabbits litter size in various parity ranged between $9.61 \%-38.44 \%$.

The rabbit livestock business will be profitable; the mother has a large litter size and is followed by good growth so that an optimal adult weight obtained. While the problems that exist in the maintenance of rabbits, including Angora, are very diverse litter sizes 3-10 heads, supported by opinions (Kumar et al., 2005) ${ }^{1}$.

A profitable rabbit livestock business, one of the indicators, is having does with a high litter size> 6 birds per birth (Abdel-Azeem et al., 2007) ${ }^{2}$ and is followed by good growth to obtain an optimal adult weight. While the problems that exist in the maintenance of rabbits, including Angora is very variation litter size, supported by opinions Kumar et al. (2005) ${ }^{1}$ values of variation of litter size German Angora rabbits were various parity ranged from $9.61 \%$ $38.44 \%$.

So, it was necessary to do multiple ovulation treatment with exogenous gonadotrophin hormone. Gonadotrophin hormones (PMSG and HCG) function to increase mature egg cells and embryos followed by pregnancy success (Park et al., 2015 ; Zhang et al., 2017 ; Satheskumar, 2006 $6^{5}$; Saratsi et al., $2002^{6}$ ). Treatment was thought to be able to overcome the litter size problem of Angora rabbits, which had a high diversity, resulting in more rabbits per mother per birth with standard birth weight.

\section{MATERIAL AND METHOD}

\section{Material}

The material in this study used ten doe Angora rabbits that had given birth once so that their reproductive status be identified and three buck Angora rabbits who were adult sex and were able to perform their reproductive functions. Individual cages made of bamboo with a size $40 \mathrm{x}$ $40 \times 50 \mathrm{~cm} 3$ equipped with grass, concentrate, and drinking places. Feeding was in the form of field grass in fresh and concentrated form (ad libitum). PMSG hormone with Folligon® is a freeze-dried for intramuscular administration after reconstituted with sterile diluent. HCG hormone with Chorulon ${ }^{\circledR}$ is the same characteristics as PMSG.

\section{Method}

The study used an experimental approach to treat exogenous PMSG and HCG hormone (P1) and control without exogenous PMSG and HCG hormone (P0), with five replications. The samples were ten doe Angora rabbits that had given birth once and three bucks Angora rabbits who had been sexually mature and were able to perform their reproductive functions. Group of rabbits treated with intramuscular exogenous gonadotrophin (IM) with $4^{\text {th }}$ day of the following steps. The $1^{\text {st }}$ day to the $3^{\text {rd }}$ day injected 50 IU of PMSG by IM in the morning after feeding at the same hour. The $4^{\text {th }}$ day no hormone treatment, and fifth day 100 HCU IU by IM in the morning after feeding at the same time (Kusuma, 19887 ; Taneja et al., 1990 ${ }^{8}$ ). After one hour of HCG administration, the does was directly mated naturally with a buck. 
The observed variables were livestock productivity, including litter size and birth weight. Litter size was the number of kits born alive or dead from a doe). Birth weight was the average weight of a kit obtained from the total weight of kits born to a doe that was born weighed a maximum of 24 hours after birth and before breastfeeding by the mother divided by the number of kits). Analysis of data by paired t-test with the Excel program with the following formula:

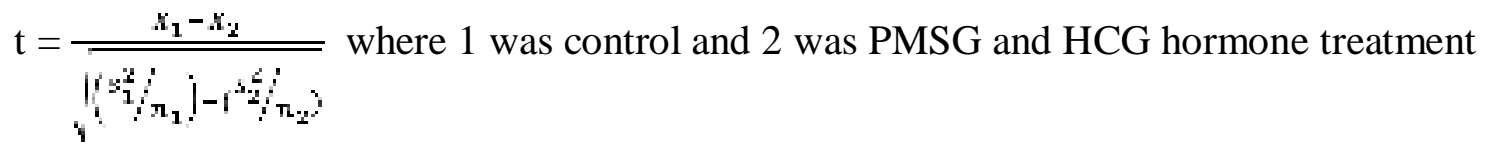

\section{RESULTS AND DISCUSSION}

\section{Litter Size}

The results of the unpaired t-test showed that the litter size of the does who received exogenous PMSG and HCG intramuscular (IM) was very significantly higher ( $\mathrm{P}>0.01)$ than the control. Supported by Niu et al. (2019) ${ }^{9}$, Zhang et al. $(2017)^{4}$ administration of the gonadotropin hormone increased mature oocyte cells and embryos. The hormone divided into two, namely Follicle Stimulating Hormone (FSH) and Luteinizing Hormone (LH) with commercial products, including PMSG (containing FSH and LH hormones with higher FSH concentrations) and HCG (containing FSH and LH with higher LH concentrations). Therefore, an increase in PMSG and HCG in the body of doe resulted in increased ovarian activity and litter size.

\section{Litter Size}

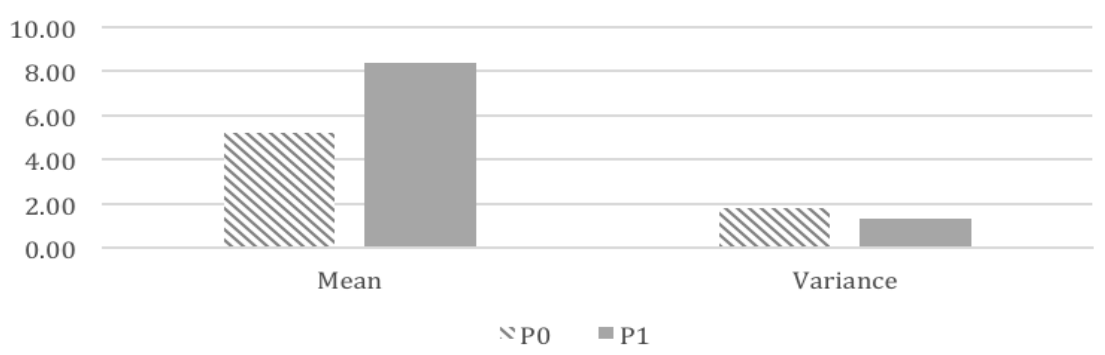

Figure 1. Mean and Variance of control (P0) and Exogenous PMSG and HCG based on litter size

Figure 1, the mean of does litter size from the group that had the PMSG and HCG treatment was $61.53 \%$ higher than the control ( $8.40 \pm 1.14$ heads vs. $5.20 \pm 1.34$ heads). The average litter size of the control group was higher than that of Kumar et al. (2005) ${ }^{1}$ German Angora rabbits in the second and third parity were $5.00 \pm 0.34$ heads and $5.14+0.42$ heads. The variance of litter size 
from the exogenous PMSG and HCG group was lower by 0.50 compared to the control group (1.30 vs. 1.80), but it was higher than the variance of the litter size by Kumar et al. (2005) ${ }^{1}$ in the second and third parity was 0.12 and 0.18 .

\section{Birth Weight}

The unpaired t-test results showed that the average birth weight of the does from the exogenous treatment of PMSG and HCG was $14.48 \%$ lower than the birth weight of the control does. Birth weight was due to a negative relationship between litter size and birth weight, meaning that increasing litter size will cause birth weight to decrease (Bollet et al., $2004^{10}$ and Kumar et al., 2015²).

The reason, birth weight is influenced by the development of kits before birth (conditions during pregnancy). If litter size increases, so the number of kits that must be supplied with food is also increased. Food supply from does during pregnancy is evenly distributed according to the number of kits. So if the number of kits is large (high litter size), each kit will get less food supply compared to other kits that the kits number is low. Also, during pregnancy, the distance between the implantation sites of the embryo is approximately the same. If there are many embryos that must be arranged for placement, the distance between embryos is shorter than that of the few embryos. So that embryo development is limited, which results in low birth weight. Because the litter size of the $\mathrm{P} 1$ treatment group was very significant than the control (P0), so the birth weight of the P1 treatment group was lower than the control (P0). The mean and variance of birth weight between control and exogenous treatment of PMSG and HCG could be seen in Figure 2.

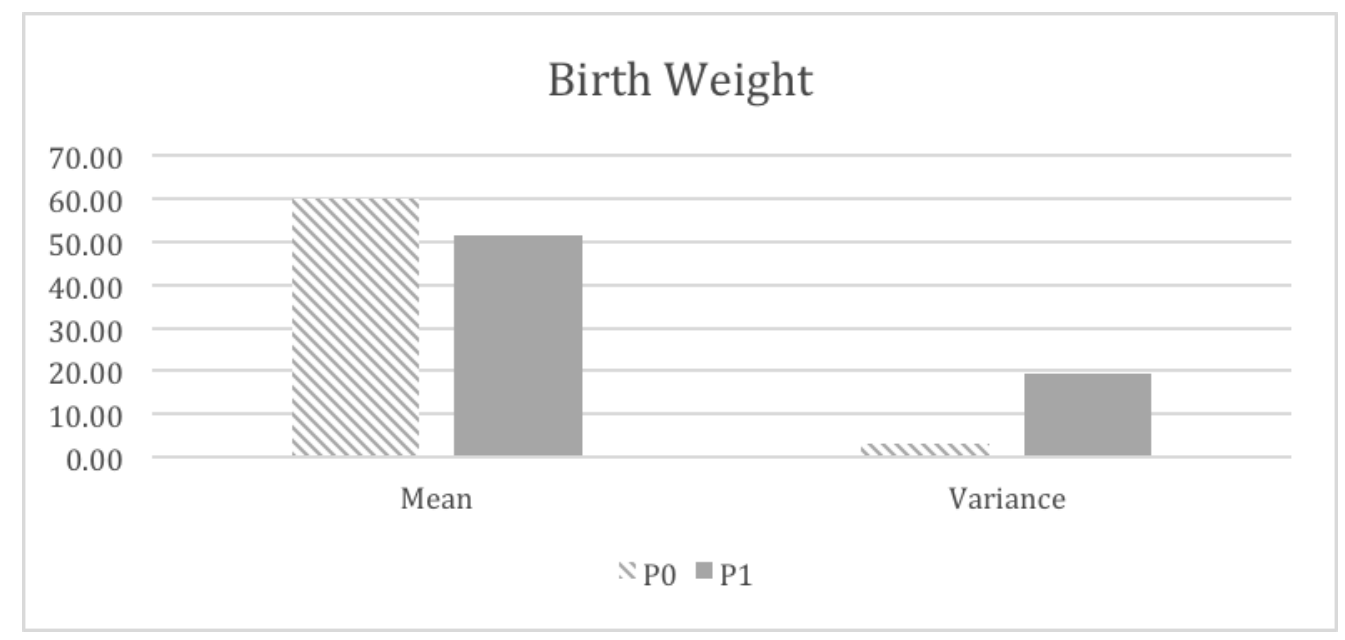

Figure 2. Mean and Variance of control (P0) and Exogenous PMSG and HCG based on birth weight 
The birth weight average of the treatment group still fulfilled the minimum standard of broiler rabbit, which is 40-50 grams (TNAU Agritech portal, 2009) ${ }^{11}$, and the minimum standard ranges from 35-40 grams to 80-90 grams (Meo et al., 2003) ${ }^{12}$. The Birth weight was higher than the lowest birth weight of various parity of German Angora rabbits 47.15-50.07 grams (Kumar et al., $2015)^{2}$, but smaller than the birth weight of various rabbit broilers ranged from 69-85 grams (Bollet et al., 2004) ${ }^{10}$. The birth weight variation of exogenous PMSG and HCG group was 19.27 gram lower than the birth weight variation of the control group 3.06 gram. The higher of litter size was smaller of birth weight and the higher birth weight variation. There is much cause of the variation in birth weight, the factors that can not be controlled by humans is the growth of fetal rabbits in the uterus that is influenced by the position of the fetus, the number of blood vessels per fetus, the distance between two fetuses. According to Szendro et al. (2019) ${ }^{13}$, fetal positions are getting closer to the end of the uterine horn, the fetal weight will increase, conversely if fetal position approaches the cervical end, the fetal weight will be lower. Rabbit does feed the fetus from the placenta through the bloodstream so that the number of blood vessels per fetus also influences the weight of birth. The distance between the fetus also affects the birth weight of the rabbit.

\section{CONCLUSIONS}

Exogenous of PMSG and HCG hormone in Angora rabbits reduced the variation of litter size (increase the uniformity of litter size) and followed by an increase in the average of livestock productivity, especially the number of children born with birth weights that fulfilled minimum standards.

\section{ACKNOWLEDGMENTS}

Authors thanks to Ministry of Research and Technology and Higher Education, Republic of Indonesia for supporting this research.

\section{REFERENCES}

Abdel-Azeem A.S., Abdel-Azim A.M.; Darwish A. A. and Omar E.M. 2007. Litter Traits In Four Pure Breeds Of Rabbits And Their Crosses Under Prevailing Environmental Conditions Of Egypt. The $5^{\text {th }}$ Inter. Con.on Rabbit Prod. in Hot Clim., Hurghada, Egypt, 39 - 51.

Kumar D., Singh U., Bhatt R.S., Risam K.S. 2005. World Rabbit Sci. 2005, 13: 113 -122.

Park S.J., Kim T.S., Kim J.M., Chang K.T., Lee H.S., and Lee D.S. 2015. Repeated Superovulation via PMSG/hCG Administration Induces 2-Cys Peroxiredoxins Expression and Overoxidation in the Reproductive Tracts of Female Mice. Molecules and Cells. 38(12): 10711078.

Zhang H., Cheng G.H., Li Y.J., Cai M.Y., Guo H.Y., Qin K.L. 2017. Superovulation and expression of follicle-stimulating hormone in young rabbit females. World Rabbit Sci. 25:167172. Doi:10.4995/wrs. 2017.4485. 
Satheskumar, S. 2006. Superovulation and Embryo recovery in two breeds of rabbits. Indian Journal of Biotechnology. 5: 54-47.

Saratsi A., Tsligianni Th., Besenfelder U., Anastasiadis A., Vainas E., and Brem G. 2002. Induction of multiple ovulation in rabbits using PMSG and hCG. Journal of the Hellenic Veterinary Medical Society. 53:228-236. Doi: http://dx.doi.org/10.12681/jhvms.15377.

Kusuma, P.S.H. 1988. Congelation des Embryons de Lapine Utilisant un Congelateur Familial. France: Memoire DEA Univ. Rennes I.

Taneja M., Pareek P.K, Jatkar P.R. 1990. Superovulation and embryo recovery in rabbits (Oryctolagus cuniculus) using different doses of pregnant mare serum gonadotrophin (PMSG). Indian J. Exp. Biol. 28 (11):1031-1033.

Niu X., Martin G.B., Liu W., Henryon M.A., Ren K. 2019. Follicle-stimilating hormone (FSH $\beta$ ) gene polymorphism and associations with reproductive traits in Rex Rabbit. Animal Reproduction Science, 207: 36-43.

Bolet G., Brun J.M., Lechevestrier S., Lopez M., Boucher S. 2004. S. Evaluation Of The Reproductive Performance Of Eight Rabbit Breeds On Experimental Farms Anim. Res. 53: 5965. Doi: 10.1051/Animres:2003043.

TNAU Agritech Portal. 2009. Animal Husbandry, Livestock: Rabbit. Agritech.tnau.ac.in. /animal_husbandry/anim_hus_rabbitbreed.html.

Meo C.Di, Gazaneo M. P., Racca C., Bovera F., Piccolo G. and Nizza A. 2004. Effect of Birth Weight and Litter Size on Productive Performance of Rabbits. Asian-Aust. J. Anim. Sci. 2004. 17 (8) : 1158-1161.

Szendro Zs., Cullere M. Atkari T., Zotte, A.D.. 2019. The birth weight of rabbits: Influencing factors and effect on behavioural, productive and reproductive traits: A review. Livestock Science 230 (103841): 1-10. 